\title{
TEM8 specific T cells target the tumor cells and tumor-associated vasculature in triple negative breast cancer
}

\author{
Tiara Byrd ${ }^{1 *}$, Kristen Fousek', Antonella Pignata', Amanda Wakefield ${ }^{1}$, Brad St Croix $^{2}$, Bradley S Fletcher ${ }^{3}$, \\ Meenakshi Hegde', Nabil Ahmed ${ }^{1}$ \\ From Society for Immunotherapy of Cancer 29th Annual Meeting \\ National Harbor, MD, USA. 6-9 November 2014
}

\section{Background}

Tumor endothelium marker 8 (TEM8) was discovered by St Croix, et. al. as one of nine gene products preferentially upregulated in the tumor-associated vs. normal endothelium [1]. Interestingly, TEM8 has also been identified as a tumor restricted antigen in triple negative breast cancers (TNBC) $[2,3]$; a clinical entity associated with a particularly poor prognosis. Being null for HER2, estrogen and progesterone receptors, targeted therapies for TNBC are quite limited.

\section{Purpose}

To use T cells expressing TEM8-specific chimeric antigen receptors (CAR) as a novel approach to target both TNBC cells and their tumor-associated vasculature.

\section{Methods/ results}

We used in silico design to construct a novel TEM8-specific CAR molecule. The antigen recognition exodomain consisted of a single chain variable fragment based on the TEM8-specific monoclonal antibody, SB5. The signaling endodomain consisted of the costimulatory molecule CD28 and CD3-zeta chain. The encoding DNA was codon optimized, synthesized and then sequence verified. We used a retroviral transduction system to express the TEM8 CAR transgene on HEK 293T, then on primary T cells. Approximately $70 \%$ of primary human T cells expressed the TEM8 CAR, as detected by flow cytometry. The expression of TEM8 was characterized using flow cytometry and western blot on a battery of TNBC lines, TEM8 transduced (modest and high expressers) cell lines as well

${ }^{1}$ Baylor College of Medicine, Houston, TX, USA

Full list of author information is available at the end of the article as TEM8 negative cell lines. TEM8 CAR T cells recognized and killed TEM8 positive target cells in an antigendependent fashion in ${ }^{51} \mathrm{Cr}$ release assays and secreted immunostimulatory cytokines upon encounter of TEM8 positive cells. There was no reactivity against TEM8 negative cell lines. No cytotoxicity or cytokine release was exhibited by $\mathrm{T}$ cells expressing an irrelevant (CD19 specific) CAR or non-transduced $\mathrm{T}$ cells from the same blood donor. We are currently testing this strategy in a vascularized orthotopic breast cancer murine model.

\section{Conclusion}

TEM8 specific CAR T cells could serve as a tumor and vascular-targeted immunotherapeutic modality for triplenegative breast cancer.

\section{Authors' details \\ ${ }^{1}$ Baylor College of Medicine, Houston, TX, USA. ${ }^{2}$ National Cancer Institute Frederick, MD, USA. ${ }^{3}$ University of Florida, Gainesville, FL, USA.}

Published: 6 November 2014

\section{References}

1. St Croix B, Rago C, Velculescu V, Traverso G, Romans KE, Montgomery E, Lal A, Riggins GJ, Lengauer C, Vogelstein B, Kinzler KW: Genes expressed in human tumor endothelium. Science 2000, 289(5482):1197 -202.

2. Gutwein LG, Al-Quran SZ, Fernando S, Fletcher BS, Copeland EM, Grobmyer SR: Tumor endothelial marker 8 expression in triple-negative breast cancer. Anticancer Res 2011, 31(10):3417-22.

3. Opoku-Darko M, Yuen C, Gratton K, Sampson E, Bathe OF: Tumor endothelial marker overexpression in breast cancer cells enhances tumor growth and metastasis. Cancer Invest 2011, 29(10):676-82.

doi:10.1186/2051-1426-2-S3-P7

Cite this article as: Byrd et al:: TEM8 specific T cells target the tumor cells and tumor-associated vasculature in triple negative breast cancer. Journal for ImmunoTherapy of Cancer 2014 2(Suppl 3):P7.

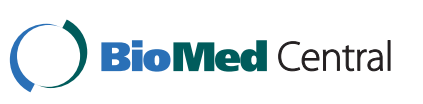

(c) 2014 Byrd et al.; licensee BioMed Central Ltd. This is an Open Access article distributed under the terms of the Creative Commons Attribution License (http://creativecommons.org/licenses/by/4.0), which permits unrestricted use, distribution, and reproduction in any medium, provided the original work is properly cited. The Creative Commons Public Domain Dedication waiver (http:// creativecommons.org/publicdomain/zero/1.0/) applies to the data made available in this article, unless otherwise stated. 